\title{
FOREST MANAGEMENT AND EROSION
}

\author{
By Prof. E. P. Stebbing, \\ UNIVERSITY OF EDINBURGH
}

$\mathrm{T}$ HE criticism has been made that Government administration annual reports from overseas often appear so belatedly that their perusal bears little relation to the probable actual position at the time. Two annual reports of the Forest Administration of Nigeria for the years 1937 and 1938 were published in 1939 (Sessional Papers Nos. 3 and 34 : Government Printer, Lagos). Nigeria has been notorious for the delay in appearance of her forestry reports. That such delays are not insuperable would appear from the fact that the report for 1938 is dated by the writer February 27, 1939, and is published in the same year!

Although a chance, it is perhaps of some significance that these two annual reports should have appeared so opportunely within a short space of time ; for taken together they may well be said to mark an epoch in the history of the progress (or in some cases want of progress) of forestry administration in that country. Both reports were written by the acting chief conservator of forests, an officer with long acquaintance of Nigeria, and especially of the northern regions. A vast improvement of form is achieved by the relegation of statistics to appendixes.

As the chief conservator says, the year 1937. was marked by several events of considerable importance. Early in the year the Anglo-French Forestry Commission completed its investigation of desiccating conditions in the Northern Provinces and the French territories beyond on the edge of the Sahara. Its report did not fulfil the high hopes which had been placed upon the Commission, whose investigations were unfortunately of too hurried a nature to afford material of great practical value. In the following July the Nigerian Government convened a Conference which met in Lagos, consisting of high officials representing several Departments, the object being to examine and make recommendations on the future policy of the Forestry Department. Great hopes were placed on the resolutions of the Conference, and 1938 opened out with very great promise for the Department. The optimism was, however, soon quenched. Once again, as so often before, a depressed financial situation at once reacted on the Forestry Department, the prospective increases were withdrawn, and the basic funds at the Department's disposal had, says the report, "necessarily to be reduced".

The reports throw into a strong light what has often been pointed out, the vacillating methods upon which forestry administration has been carried on by the Governments of Colonios. In 1937, as a result of a conference at which some of the highest members of the administration were present, a forest policy was determined upon and provision made to put it into force the following year. Almost before the ink of the attached signatures was dry, funds were withdrawn and once again stagnation was to supervene.

That in the interests of the country as a whole, continuity of the work of the Forest Department should be maintained, is illustrated by the following remarks in the 1937 report :

"The general examination of forests by field officers has revealed the immense importance and urgent necessity of planning. The continued and universal damage to unreserved forest and the indiscriminate encroachment in reserves emphasise the necessity of distributing the available staff to the best advantage. . . . Reservation and consolidation of the existing reserves must, of course, take first place. . . . In areas where reservation has not yet reached the required percentage and where cocoa is a popular crop, planning is all the more necessary. Many such areas are unfitted climatically to maintain cocoa as a permanent crop and the wildly unbalanced expansion which takes place after a boom must not only lead to disaster in the area itself but must also have repercussions in adjacent climatic 'tension' areas."

In his 1938 report the acting chief conservator writes that "Reservation, management and research; each must play its part"; but adds, after stating that forest reserves established must as soon as possible be placed under some form of management, "no unavoidable delays can be permitted to stand in the way of building up the total of reserved forest required".

The acting chief conservator does not appear to have quite made up his mind as to whether the most important of the duties of the Department at the present time are "to secure the existing forest estate" or the "building up of the total reserved forest required". He rightly says that no great progress in forest management can be made until the necessary percentage of forest estate is secured, and continues : "It is nevertheless equally necessary, because of the limited area of merchantable forest in Nigeria, to place under management such a proportion of this area as has been secured, without diverting to the purpose an undue proportion of the staff or funds available. Comparisons, invidious sometimes, are made with India and other Colonies in the matter of relative progress in the different branches of the Forest Department, but there is no real analogy. Our merchantable forest wealth, which is an Imperial asset as much as a Nigerian one, must be put under management as soon as possible and cannot wait for the completion of the whole framework of reservation throughout the country, a task which may take anything from fifty to eighty years at the present rate of progress."

Why? Is this logical ? How much of the forests of these proposed future reserves will remain, and what will be the condition of the area left (and that of the surrounding countryside) at the end of this period of $50-80$ years ?

As to this comparison with India and Burma, the Burma teak forests were very much of an Imperial asset when the late Sir Dietrich Brandis began, as soon as he joined in Pegu, his enumer- 
ation surveys to ascertain the stocking. By this work he was able to maintain the continuity of supply to the European and Indian markets, which was imperative, whilst at once putting an end to unchecked fellings. But this work did not hold up forest reservation either in India or Burma. By the end of the century, a period of little more than thirty years, the framework of reservation throughout Indian and accessible Burmese forests had been accomplished, whilst considerable managoment had been introduced into the forests. The pity is that after about the same number of years of forestry in Nigeria the Forestry Department should have much forest reservation still to be undertaken, owing to the fact that its real position in the Administration has never until recently been understood, save to be regarded primarily as a revenue producer.

Perhaps one of the most important and progressive pieces of work the Department has undertaken during the last few years has been an outcome of the Anglo-French Commission, on the British side. Two special anti-desiccation and vegetational survey teams were appointed to carry out desiccation investigations in the Northern Sokoto, Katsina, and Kano Provinces. A special report on the Sokoto area has produced, says the chief conservator, "a very interesting set of conclusions, which are briefly that 'desiccation' in Sokoto in the form of encroachment of the Sahara is not apparent, but that all the conditions present are due to the activities of man and of domestic animals". If the writer will study the history of parts of the south-west Sahara, he will find, to quote one instance, that the howling Desert of Mauretania, situated some 400 kilometres to the west of Timbuctoo, was the centre of the great Empire of Ghana from the ninth until the eleventh centuries, when the region consisted of smiling fertile lands. It now forms part of the Sahara. The great desert did not advance over the area in sandwaves. As the writer says above, "the activities of man and domestic animals" gradually produced the result, and the region was added to the Sahara; just as the areas comprised in Sokoto and Katsina, if the present-day activities continued unchecked in the two provinces, would infallibly be added to the great desert, which would have thus 'encroached' on the area.

Members of the Society of American Foresters met in San Francisco last November. Charles A. Connaughton, of the U.S. Forest Service, discussed (Science Service, Nov. 21, 1939) problems of watershed control; they were difficult, he pointed out, because owners of watershed areas seldom receive the benefits of control measures, which cost money and labour on the spot but go mainly for the help of lands farther downstream !. . . He continued: "Rangeland research is needed for the solution of problems arising out of overgrazing, which not only brings about the displacement of good forage species by weeds but even the destruction of the soil itself through erosion. Research now in hand has already suggested that native grasses and other plants, rather than exotics, may be the best for rangeland restoration, but more research is needed to arrive at really definite conclusions. Another possible result of researches now in progress is the upsetting of the old idea, accepted almost as an axiom, that livestock and larger game animals cannot use the same range without robbing each other. Apparently, both livestock and wildlife can be produced without serious conflict on most ranges."
The forestry remedial measures (given in the 1938 Nigerian report) to be put into force in Sokoto are excellent, and indicate that this serious problem is now to be tackled with understanding; and, unlike the American rangeland and watershed problem (though Africa has the same elsewhere), the amelioration work to be undertaken in Sokoto, and extended eastward, will benefit alike the people within the area and others situated to the south.

In the Forest Report for Palestine for the period 1936-39 (Printing and Stationery Office, Jerusalem, 1939 ), it is stated that the total land area is some 10,000 square miles; the hills are mostly composed of limestones, with basalt intrusions in the northeast, whilst the plains are deeply covered with alluvium. The climatic desert accounts for something less than half the area; of the remainder, 45 per cent are plains and 55 per cent hilly country. The state of the hills is considered to be unsatisfactory, as most of the surface is eroded, and probably less than 1 per cent is agricultural land in good condition. The hills, it is said, were undoubtedly once covered with soil and forest, whereas they are now an artificial desert due to overgrazing. The river valleys are desolated by floods and the deposition of infertile detritus, the river beds are choked, and road and railway embankments and bridges frequently damaged.

The Forest Department, formed only in 1936, owing to the outbreaks and unrest which supervened so soon after, has scarcely had time to get well into the saddle. Moreover, promised grants were withdrawn, inevitably, perhaps, owing to the unrest. But the Department has already been able to contribute some valuable information on the subject of erosion in the Middle East. On the question of reservation of land areas for afforestation the report states: "In the course of time previous to 1936, the natural vegetation was cleared from nearly all the fertile areas of Palestine, and such vestiges as remained were on the most rocky and barren land. Even there the vegetation was almost ruined by excessive grazing and uncontrolled cutting. In consequence, the present value of the vegetation and of the land on which it stands is very low, and most of the Forest Reserves cannot be made highly productive without many years of careful management. Closure and protection, however, will very early result in the checking of erosion and flooding, and are therefore of the utmost value."

Man's old habits-fire and excessive grazinghave probably been the chief two causes for the present condition of so much of Palestine. On the subject of fire, the report says that the climate of the country, with its long summer drought, atmospheric desiccation, and dry, hot winds, is very conducive to forest fires, which would be more serious but for the sparseness of the vegetation in most places--which tells its own tale as to the downgrade of the country as a home for man, or even for his goats. The present position of grazing shows the determining factor in this latter question. The following paragraph might have been written of other areas within the British Empire; but here it possesses its own significance: "Except for the wellbred cows on a few modern dairy farms which grow fodder in irrigated fields, the grazing animals of Palestine have to depend on the grass, shrubs, and young trees which Nature provides on uncultivated land. Their only change of diet is the stubble on the cereal lands after harvest. Centuries of such 
treatment have produced a tough and agile goat which can consume organic matter of almost any type. The sheep, mostly of the fat-tailed breed, are also very hardy. The camel, fortunately less common in the northern districts, eats what the goat cannot reach. No attempts have been made to estimate the permanent carrying capacity of the land, the number of animals grazed is limited only by drought, starvation and disease; and the vegetation is destroyed over large areas, which have become artificial deserts in spite of good climatic and geological factors. Soils were nearly everywhere excellent before they were removed by erosion. All other forms of damage fade into insignificance beside the destruction caused by grazing, though the process is accelerated by cutting and uprooting."

Yet there are still some who dispute that obvious factor on the globe, the man-made desert-both of the past, and those of more modern origin, and in the making.
Forestry problems of increasing magnitude and importance are many in the British Colonial Empire.

The welcome and wide-visioned Colonial policy recently announced by the Secretary of State offers, it may be hoped, opportunity that in the future continuity in a forest policy, duly drawn up and sanctioned, may be persisted in, whatever vicissitudes befall the Colonial budget; and, above all, that recognition should be accorded to the factor that the scheme for reservation of the forest areas in any Colony considered needful to its economic progress, the protection of its water supplies, etc., upon which the agricultural prosperity depends, should take precedence of other work. The policy, as laid down for Nigeria by the 1937 Committee, that foreshadowed in the Palestine Report, and those so often voiced for other Colonies, should now become practical politics in view of Mr. Malcolm Macdonald's masterly White Paper.

\section{ECONOMIC PROBLEMS OF INDUSTRIAL SCIENTISTS}

\begin{abstract}
A SERIES of regional conferences to discuss the economic problems of men of science and engineers employed in industry has recently been held in London, Liverpool and Manchester. Others are to follow, and it is intended that a national conference shall be held in the autumn in order to collate the information obtained at the regional conferences. The conferences are being organized by the Association of Scientific Workers, but many members of other professional organizations attended the meetings and took part in the papers and discussions. It is hoped that this collaboration will continue and increase as a result of the interest aroused.

The London regional conference, held on March 9, with Prof. F. G. Donnan in the chair, was opened by Mr. Hugh N. Linstead, with a general discussion on the place of the scientific worker in industry and on the role of professional organizations. He pointed out that, in view of the great importance of the role of the scientist in modern industry, the discrepancies between the salaries of scientists in industry as compared with those in administrative positions can only be rectified by scientists organizing themselves. Such an organization must protect the interests of the scientific worker, but be broad enough to consider the problems of the industry and the employer as well. In spite of the prejudice against trade unionism among professional workers, the trade unions play an essential part in industry, and both the scientist and the community suffer from lack of this type of organization among scientists.
\end{abstract}

This was followed by a paper by Mr. J. Stewart Cook on the question of salaries, increments, overtime, etc. His paper consisted of a factual analysis of the data available in these questions as they affect both graduate scientists and assistants, and was based on the results of a questionnaire sent out by the Association of Scientific Workers, and on data published by the Institute of Chemistry. He considers that salaries will only be uniformly adequate and satisfactory when scientists are organized on such a basis that they can and will refuse to take jobs below prescribed rates. He pointed to the good record of the British Association of Chemists in this respect, attributing its success to the policy of maintaining an appointments board, backed up by an unemployment scheme.

The rights of publication were discussed by Mr. H. T. Rhodes, and the question of holidays and opportunities for study by Mr. J. L. Pinder. The latter stressed the necessity for adequate holidays and opportunities to attend scientific lectures, if the scientist is to produce his best work. $\mathrm{He}_{\theta}$ is in favour of a 5-day week. The question of adequate time for study as well as for recreation is essential for assistants studying for degrees. He considers their position in this respect is often unsatisfactory.

The problems of the assistant were dealt with by Mr. R. Peter, himself an assistant. The assistant is faced with the double task of satisfying the employer by day and the examiner by night. The principal requirements of assistants are (1) standardization of working hours throughout industry, (2) standardization of wages based on some grading system of age and qualifications, (3) a definition of work expected on engagement and a limitation of this, in general, to technical matters, (4) allowance of adequate time for study and recreation and provision of financial assistance where necessary for the cost of study.

A paper was then given by Mr. F. W. Adams dealing with the legal side of scientific employment, in which he discussed the questions of contracts, of copyright and the right to seek alternative employment.

Prof. J. D. Bernal, in summing up, pointed out the similarities and the differences in the position of scientists in this War and that of 1914-18. Since 1918 the scientist and the laboratory have become an integral part of industry, but there has not been the development of organization of scientists which has occurred in other spheres of industry. Bad conditions for scientists mean a depression in productivity of industry. The increasing number of assistants entering the ranks of qualified scientists means that the whole range of the problem from assistant to directorate must be tackled, as an anomaly in any 